\title{
Negotiating and Transforming the Public Sphere: African American Political Life in the Transition from Slavery to Freedom
}

\author{
Elsa Barkley Brown
}

O

n April 15, 1880, Margaret Osborne, Jane Green, Susan Washington, Molly Branch, Susan Gray, Mary A. Soach and "over two hundred other prominent sisters of the church" petitioned the Richmond, Virginia, First African Baptist Church's business meeting to allow women to vote on the pastor:

We the sisters of the church feeling that we are interested in the welfare of the same and also working hard to finish the house and have been working by night and day . . . We know you have adopted a law in the church that the business must be done by the male members. We don't desire to alter that law, nor do we desire to have anything to do with the business of the church, we only ask to have a vote in electing or dis-

An earlier version of this paper was presented at "The Black Public Sphere in the Reagan-Bush Era Conference," Chicago Humanities Institute, University of Chicago in October 1993, where I benefitted from the comments of Kenneth Warren and the discussion of the conference participants. Thanks also to Carol A. Breckenridge and to two anonymous reviewers for their comments, and to Nataki $\mathrm{H}$ Goodall for her critical eye and unflagging support. The writing of this essay was facilitated by a research leave from the University of Michigan and research fellowships at the W.E.B. Du Bois Institute for Afro-American Research, Harvard University; and the Virginia Center for the Humanities.

Public Culture 1994, 7: 107-146

(C) 1994 by The University of Chicago. All rights reserved.

0899-2363/95/0701-0008\$01.00 
missing him. We whose names are attached to this petition ask you to grant us this privilege. ${ }^{1}$

The circumstances surrounding these women's petition suggest the kinds of changes taking place internally in late-nineteenth and early-twentieth century black Richmond and other southern black communities. In the immediate postCivil War era women had voted in mass meetings and Republican Party conventions held at First African, thus contradicting gender-based assumptions within the larger society about politics, political engagement and appropriate forms of political behavior. Now, women sitting in the same church were petitioning for the right to vote in an internal community institution, couching the petition in terms designed to minimize the request and avoid a challenge to men's authority and position.

Scholars' assumptions of an unbroken line of exclusion of African American women from formal political associations in the late-nineteenth century has obscured fundamental changes in the political understandings within African American communities in the transition from slavery to freedom. Women in First African and in other arenas were seeking in the late-nineteenth century not a new authority but rather a lost authority, one they now often sought to justify on a distinctively female basis. As these women petitioned for their rights within the church and as other women formed voluntary associations in turn-of-thecentury Richmond they were not, as often depicted in the scholarly literature, emerging into the political arena through such actions. Rather these women were attempting to retain space they traditionally had held in the immediate postemancipation period. This essay explores the processes of public discourse within Richmond and other southern black communities and the factors which led to increasingly more clearly gendered and class spaces within those communities to understand why women by the 1880 s and 1890 s needed to create their own pulpits from which to speak - to restore their voices to the community. This exploration suggests how the ideas, process, meanings and practice of freedom changed within late-nineteenth-century southern African American communities and what the implications of those changes may be for our visions of freedom and for the possibilities of African American community in the late-twentieth century.

1. Petition of Mrs. Margaret Osborne, et al. To the deacons and members of the First Baptist Church, April 15, 1880, recorded in First African Baptist Church, Richmond City, Minutes, Book II, June 27, 1880 (microfilm), Archives, Virginia State Library and Archives, Richmond, Virginia (hereafter cited as FABC). 
After emancipation, African American men, women and children, as part of black communities throughout the South struggled to define on their own terms the meaning of freedom and in the process to construct communities of struggle. Much of the literature on Reconstruction portrays freed African Americans as rapidly and readily adopting a gendered private-public dichotomy. ${ }^{2}$ Much of the literature on the nineteenth-century public sphere constructs a masculine liberal bourgeois public with a female counterpublic. ${ }^{3}$ This essay, focusing on the civic geography of post-Civil War black Richmond suggests the problematic of applying such generalizations to African American life in the late-nineteenth century South. In the immediate post-emancipation era black Richmonders enacted their understandings of democratic political discourse through mass meetings attended and participated in (including voting) by men, women and children and through mass participation in Republican Party conventions. They carried these notions of political participation into the state Capitol engaging from the gallery in the debates on the constitutional convention floor.

2. The idea of the immediate adoption of a gendered public-private dichotomy pervades much of the historical literature on post-Civil War black communities. It is most directly argued by Jacqueline Jones: "the vitality of the political process, tainted though it was by virulent racial prejudice and violence, provided black men with a public forum distinct from the private sphere inhabited by their womenfolk. Black men predominated in this arena because, like other groups in nineteenth-century America, they believed that males alone were responsible for-and capable of-the serious business of politicking," Labor of Love, Labor of Sorrow: Black Women, Work, and the Family from Slavery to the Present (New York: Basic Books, 1985), 66. But it is also an accepted tenet of otherwise rigorous analyses such as Eric Foner, Reconstruction: America's Unfinished Revolution 1863-1877 (New York: Harper and Row, 1988), esp. 87.

3. Many recent discussions of the public sphere among U.S. scholars have orbited around the work of Jürgen Habermas whose 1962 Strukturwandel der Offentlichkeit was published in 1989 in English as The Structural Transformation of the Public Sphere: An Inquiryinto a Category of Bourgeois Society, trans. Thomas Burger with assistance of Frederick Lawrence (Cambridge: MIT Press). See also, Jürgen Habermas, “The Public Sphere: An Encyclopedia Article (1964),” New German Critique 1 (Fall 1974): 49-55. Critics who have emphasized the masculine bias in the liberal bourgeois public sphere and posited a female counterpublic include Nancy Fraser, "Rethinking the Public Sphere: A Contribution to the Critique of Actually Existing Democracy" and Mary Ryan, "Gender and Public Access: Women's Politics in Nineteenth-Century America," both in Habermas and the Public Sphere, ed. Craig Calhoun (Cambridge: MIT Press, 1992), 109-142 and 259-289, respectively. See also, Nancy Fraser, "What's Critical About Critical Theory? The Case of Habermas and Gender," in Nancy Fraser, Unruly Practices: Power, Discourse, and Gender in Contemporary Social Theory (Minneapolis: University of Minnesota Press, 1989); Mary Ryan, Women in Public: Between Banners and Ballots, 1825-1880 (Baltimore: John Hopkins University Press, 1990); Joan B. Landes, Women and the Public Sphere in the Age of the French Revolution (Ithaca: Cornell University Press, 1988); Rita Felski, Beyond Feminist Aesthetics: Feminist Literature and Social Change (Cambridge: Harvard University Press, 1989), 154-182. Focusing on contemporary politics, Iris Marion Young offers a critique of an ideal public sphere in which the universal citizen is not only masculine but also white and bourgeois, Justice and the Politics of Difference (Princeton: Princeton University Press, 1990). 

political discourse was the church as a foundation of the black public sphere. ${ }^{4}$ In the post-slavery era, church buildings also served as meeting halls and auditoriums as well as educational and recreational facilities, employment and social service bureaus and bulletin boards. First African, especially, with a seating capacity of nearly 4000 , was the site of large political gatherings. Schools such as Richmond Theological Seminary and Richmond Colored High and Normal School held their annual commencement exercises at First African Baptist, allowing these events to become community celebrations. Other groups, such as the Temperance Union were regularly granted the church for their meetings or rallies. As a political space occupied by men, women and children, literate and nonliterate, ex-slave and formerly free, church members and nonmembers, the availability and use of First African for mass meetings enabled the construction of political concerns in democratic space. This is not to suggest that official versions and spokespersons were not produced, but these official versions were the product of a fairly egalitarian discourse and, therefore, represented the conditions of black Richmonders of differing classes, ages and genders. Within black Richmonders' construction of the public sphere, the forms of discourse varied from the prayer to the stump speech to the testimonies regarding outrages against freedpeople to shouted interventions from the galleries into the debates on the legislative floor. By the very nature of their participation - the inclusion of women and children, the engagement through prayer, the disregard of formal rules for speakers and audience, the engagement from the galleries in the formal legislative sessions-Afro-Richmonders challenged liberal bourgeois notions of rational discourse. Many white observers considered their unorthodox political engagements to be signs of their unfamiliarity and perhaps unreadiness for politics. ${ }^{5}$

4. For a study that conceptualizes the history of the black church in relation to Habermas's theory of the public sphere, see Evelyn Brooks Higginbotham, Righteous Discontent: The Women's Movement in the Black Baptist Church 1880-1920 (Cambridge: Harvard University Press, 1993), esp. 7-13. Higginbotham describes "the black church not as the embodiment of ministerial authority or of any individual's private interests and pronouncements, but as a social space for discussion of public concerns" (1993:10).

5. Similar negotiations and pronouncements occurred in other post-emancipation societies. For a discussion of the ways in which British colonial officers sought to impose ideas of a liberal democratic moral and political order, with its attendant gender relations, on former slaves in the West Indies and then pronounced these ex-slaves incapable of responsible citizenship when they failed to wholly adopt such, see Thomas C. Holt, "The Essence of the Contract': The Articulation of Race, Gender, and Political Economy in British Emancipation Policy, 1838-1866," paper presented at "The Black Public Sphere in the Reagan-Bush Era Conference," Chicago Humanities Institute, The University of Chicago, October 1993 (cited with permission of Holt). 
In the decades following emancipation as black Richmonders struggled to

achieve even a measured amount of freedom, the black public sphere emerged as more fractured and perhaps less democratic at the end of the nineteenth century, yet even then it retained strong elements of a democratic agenda. This essay examines the changing constructions of political space and community discourse in the post-emancipation era.

\section{Envisioning Freedom}

In April 1865, when Union troops marched into Richmond, jubilant African American men, women and children poured into the streets and crowded into their churches to dance, kiss, hug, pray, sing and shout. They assembled in First African, Third Street African Methodist, Ebenezer and Second African not merely because of the need to thank God for their deliverance but also because the churches were the only institutional spaces, and in the case of First African certainly the largest space, owned by African Americans themselves. ${ }^{6}$ As the process of reconstruction unfolded, black Richmonders continued to meet regularly in their churches, now not merely to rejoice. If Afro-Richmonders had thought freedom would accompany emancipation, the events of the first few weeks and months of Union occupation quickly disabused them of such ideas. Throughout the summer and fall of 1865 black Richmonders reported numerous violations of their rights. Among them were pass and curfew regulations designed to curtail black mobility and force African American men and women out of the city to labor in the rural areas. Pass and curfew violators (800 in the first week of June) were detained in bullpens - one for women and children, a separate one for men-away from and often unknown to family members. Black Richmonders also detailed numerous incidents of disrespectful treatment, verbal abuse, physical assault and torture. "Many poor women" told "tales of their frights and robberies"; vendors told of goods destroyed by military police. Private homes were not immune to the intrusions of civilian and military white men. One couple was confronted by soldiers, one of whom stood over them in bed "threatening to blow

6. The question of ownership was one of the first issues Afro-Richmonders addressed, as antebellum law had required the titles be in the names of white male supervising committees although the black congregants had themselves bought and paid for the buildings. Through a series of struggles black churchgoers had by the end of 1866 obtained titles to all of their church buildings. See New York Tribune, June 17, 1865; Peter Randolph, From Slave Cabin to Pulpit (Boston: Earle, 1893), 94-95; John Thomas O'Brien, Jr., "From Bondage to Citizenship: The Richmond Black Community, 1865-1867" (Ph.D. diss., University of Rochester, 1974), 273-275. 
out their brains if they moved" while others "pillage[d] the house of money, watches, underclothing, etc." Many spoke of the sexual abuse of black women: "gobbling up of the most likely looking negro women, thrown into the cells, robbed and ravished at the will of the guard." Men and women in the vicinity of the jail testified "to hearing women scream frightfully almost every night."

7. Statement of Jenny Scott, wife of Ned Scott, colored, June 8, 1865; Statement of Richard Adams, colored, June 8, 1865; Statement of Nelson E. Hamilton, June 9, 1865; Statement of Lewis Harris, June 9, 1865; Statement of Wm. Ferguson, June 9, 1865; Statement of Albert Brooks, colored, June 10, 1865; Statement of Thomas Lucas, colored, June 12, 1865; Statement of Washington Hutchinson, Summer 1865; Statement of Edward Davenport, n.d.; Statement of Bernard H. Roberts, n.d.; Statement of Albert Williams, n.d.; Statement of Thos. J. Wayer, n.d.; Statement of Harry R. Jones, n.d.; Statement of Wellington Booker, n.d.; Statement of Stephen Jones, n.d.; Statement of John Oliver of Mass., n.d.; Wm. M. Davis to Col. O. Brown, June 9, 1865, all in Records of the Assistant Commissioner for the State of Virginia, Bureau of Refugees, Freedmen and Abandoned Lands, 1865-1869, Record Group 105, M1048, reel 59, National Archives, Washington, D.C.; New York Tribune, June 12, 17, August 1, 8, 1865; Richmond Times, July 26, 1865; S.E.C. (Sarah Chase) to Mrs. May, May 25, 1865, in Henry L. Swint, ed., Dear Ones at Home: Letters from Contraband Camps (Nashville: Vanderbilt University Press, 1966), 159-160; Julia A. Wilbur in The Pennsylvania Freedman's Bulletin, I (August 1865), 52, quoted in John T. O'Brien, "Reconstruction in Richmond: White Restoration and Black Protest, April-June 1865," Virginia Magazine of History and Biography, 89, 3 (July 1981): 273, 275.

8. New York Tribune, August 1, 8, 1865. One of the most neglected areas of Reconstruction history and of African American history in general, is that of violence against women. This has led to the still prevalent assumption that black women were less likely to be victims of racial violence and the generalization that this reflects the fact that black women were less threatening than black men. Historian W. Fitzhugh Brundage, for example, concludes that black women had "greater leeway" to "voice their opinions and anger without suffering extralegal violence themselves," Lynching in the New South: Georgia and Virginia, 1880-1930 (Urbana: University of Illinois Press, 1993), 80$81,322-323 n$. This reflects both the emphasis on lynching as the major form of racial violence, and the limited historical attention to the black women who were lynched (at least fifteen between 1889 and 1898; at least seventy-six between 1882 and 1927). Even those ostensibly attuned to issues of gender and sexuality still assume that "the greatest violence was reserved for black men"; see, for example, Martha Hodes, "The Sexualization of Reconstruction Politics: White Women and Black Men in the South after the Civil War," Journal of the History of Sexuality 3 (January 1993): 404. Yet the evidence from Richmond and elsewhere suggests that the extent of violence against black women is greater than previously recognized, even greater than reported at the time. One North Carolina man, Essic Harris, giving testimony to the Senate committee investigating Ku Klux Klan terror, reported the rape of black women was so frequent as to be "an old saying by now." Essic Harris testimony, July 1, 1871, in U.S. Congress, Testimony Taken by the Joint Select Committee to Inquire into the Condition of Affairs in the Late Insurrectionary States Vol.: North Carolina (Washington: GPO, 1872), 100. Only recently have historians begun to uncover and analyze sexual violence against black women as an integral part of Reconstruction history. See for example, the dissertation-in-progress by Hannah Rosen, University of Chicago, which examines the rapes connected with the 1866 Memphis race riot. See also, Catherine Clinton, "Reconstructing Freedwomen," Divided Houses: Gender and the Civil War, eds. Catherine Clinton and Nina Silber (New York: Oxford University Press, 1992), chapter 17. 
The regular meetings in the African churches, originally ones of jubilation, quickly became the basis for constructing a discourse about freedom and organizing large-scale mass protest. On June 10, 1865 over 3000 assembled at First African to hear the report of the investigating committee which had conducted hearings and gathered the evidence and depositions necessary to present black Richmonders' case directly to Governor Francis H. Pierpoint and to the "chief head of all authority," the President of the United States. The protest memorial drawn up during the meeting was ratified at meetings in each of the other churches and money was raised through church collections to send six representatives (one from each church in Richmond and one from First Baptist, Manchester) to Washington. On Friday, June 16, these delegates delivered the mass meeting's protest directly to President Andrew Johnson:" "Mr. President: We have been appointed a committee by a public meeting of the colored people of Richmond, Va., to make known . . . the wrongs, as we conceive them to be, by which we are sorely oppressed." In their memorial, as in their meetings, black Richmonders recounted not merely the abuses but they also used their individual stories to construct a collective history and to combat the idea of being "idle negroes" unprepared for freedom. ${ }^{10}$

We represent a population of more than 20,000 colored people, including Richmond and Manchester, . . . more than 6,000 of our people are members in good standing of Christian churches, and nearly our whole population constantly attend divine services. Among us there are at least 2,000 men who are worth $\$ 200$ to $\$ 500 ; 200$ who have property valued at from $\$ 1,000$ to $\$ 5,000$, and a number who are worth from $\$ 5,000$ to $\$ 20,000 \ldots$.

9. New York Tribune June 12, 17, 1865.

10. The Richmond Times (May 24, 1865), in refusing to publish black Richmonders' statements of protest, reasoned that they were mistaken in believing that they were all oppressed by the military and civilian officials; only the "idle negroes" were targets of military restrictions and inspections. Throughout the early months of emancipation both white southerners and white Unionists defined freedpeople's mobility in search of family or better jobs and in expression of their new found freedom as evidence of an unwillingness to work. Similarly, those who chose to vend goods on city streets rather than signing work contracts with white employers were seen as lazy or idle. See, O'Brien, "From Bondage to Citizenship," 117-131; see also various communications among the military command reprinted in U.S. War Department, The War of the Rebellion: A Compilation of the Official Records of the Union and Confederate Armies, Series I, Volume XLV, Part III-Correspondence, Etc. (Washington: GPO, 1894), 835, 932-933, 1005-1006, 1091, 1094-1095, 1107-1108, 11311132 . 
The law of Slavery severely punished those who taught us to read and write, but, not withstanding this, 3,000 of us can read, and at least 2,000 can read and write, and a large number of us are engaged in useful and profitable employment on our own account.

The community they described was one based in a collective ethos; it was not merely their industry but also their responsibility which was the basis on which they claimed their rights.

None of our people are in the alms-house, and when we were slaves the aged and infirm who were turned away from the homes of hard masters, who had been enriched by their toil, our benevolent societies supported while they lived, and buried when they died, and comparatively few of us have found it necessary to ask for Government rations, which have been so bountifully bestowed upon the unrepentant Rebels of Richmond.

They reminded Johnson of the efforts black men and women in Richmond had taken to support the Union forces against the Confederacy.

During the whole of the Slaveholders' Rebellion we have been true and loyal to the United States Government; . . . We have given aid and comfort to the soldiers of Freedom (for which several of our people, of both sexes, have been severely punished by stripes and imprisonment). We have been their pilots and their scouts, and have safely conducted them through many perilous adventures.

They declared themselves the loyal citizens of the United States, those the federal government should be supporting. And finally they invoked the religious destiny that emancipation had reaffirmed, reminding the President of a "motto once inscribed over the portals of an Egyptian temple, 'Know all ye who exercise power, that God hates injustice!'"11

Mindful of others' versions of their history, standing and entitlements, black Richmonders also moved to have their own story widely circulated. When local white newspapers refused to publish their account, they had it published in the

11. New York Tribune, June 17, 1865. 

freedom. ${ }^{13}$ The story told in those mass meetings, published in northern white newspapers, carried in protest to Union officials, was also carried into the streets as black Richmonders inserted themselves in the preexisting national political traditions and at the same time widened those traditions. John O'Brien has noted that in the immediate aftermath of emancipation, black Richmonders developed their own political calendar, celebrating four civic holidays: January 1; George Washington's birthday; April 3 (emancipation day); and July $4 .{ }^{14}$ White Richmonders were horrified as they watched former slaves claim civic holidays and traditions they believed to be the historical possession of white Americans and occupy spaces, like Capitol Square, which had formerly been reserved for white residents. ${ }^{15}$

The underlying values and assumptions that would pervade much of black people's political struggles in the city were forged in slavery and war and in the weeks following emancipation. Military regulations which limited black mobility and made finding and reunifying family members even more difficult placed the economic interests of white men and women above the material and social interests of African Americans. The bullpens, which detained many away from their families, and the raids on black homes, which made all space public and subject to the interests of the state, obliterated any possible distinctions between public and private spheres. Demanding passes and evidence of employment denied black Richmonders the right to act and to be treated not as economic units and/or

12. Black Richmonders were countering the very different image of their community put forth not only by white southerners but also by Union officers. Major-General H. W. Halleck, for example, emphasized the goodwill between Rebel and Union soldiers, both "brave and honest men, although differing in opinion and action"; justified the military restrictions on African Americans; and reported a lack of marriage relationships among African Americans "and the consequent irresponsibility of the parents for the care and support of their offspring." He argued that "colored females," especially, needed legal restrictions, supervision and suitable punishments, because "being released from the restraints imposed by their former masters and mistresses, . . . naturally fall into dissolute habits." H. W. Halleck, Major-General, Commanding, Headquarters Military Division of the James, Richmond, Va. to Hon. E. M. Stanton, Secretary of War, June 26, 1865, in U.S. War Department, The War of the Rebellion, 1295-1297. Halleck was one of the Union officers who was reassigned to a different command as a result of the June protest.

13. O'Brien details these meetings in "From Bondage to Citizenship," chapters 6-9.

14. O'Brien, "From Bondage to Citizenship," 326.

15. See, for example, Richmond Enquirer, February 23, 1866; Richmond Dispatch, July 6, 1866; Richmond Times, July 6, 1866. 
property but as social beings and family members. The difficulty of finding decent housing at affordable prices further impeded freedpeople's efforts to bring their families together. All of these obstacles to and expectations of family life were part of what Eric Foner speaks of as the "'politicization' of every day life."16

These political issues underpinned Afro-Richmonders' petition to Johnson and would continue to underpin their political struggles in late-nineteenth century Richmond. Even as they fashioned individual stories into a collective history, black Richmonders could and did differ on the means by which they might secure freedom-vigorously debating issues such as the necessity of confiscation. ${ }^{17} \mathrm{But}$ they also understood freedom as a collective struggle. When they entered the formal political arena through Republican party politics in 1867 this understanding was the foundation for their initial engagement with issues of suffrage and democracy. As Julie Saville has observed for South Carolina, freedpeople in Richmond "were not so much converted to the Republican party as they were prepared to convert the Republican party to themselves." 18 The post-Civil War southern black public sphere was forged in jubilation and struggle as African American men, women and children claimed their own history and set forth their own political ideals.

All the resources of black Richmonders became elements in their political struggles. The Richmond Whig, intending to ridicule the inappropriateness of freepeople's behaviors and assumptions, highlighted the politicized nature of all aspects of black life during Reconstruction; the freedpeople's "mass meetings, committee meetings, and meetings of the different societies all have political significance. The superstitions of the colored people are availed on, and religion and Radicalism are all jumbled together. Every night they have meetings and musterings, harangues and sermons, singing and praying - all looking to political results. "19 Similarly the Richmond Dispatch reported an 1867 Republican meeting which began with "Harris, colored" offering "the most remarkable" prayer "we have ever heard. It was frequently interrupted by laughter and manifestations of applause":

Oh, Lord God, bless our enemies-bless President Johnson. We would not even have him sent to hell. Come, oh come, good Lord, and touch

16. Foner, Reconstruction, 122.

17. Richmond Dispatch, April 19, 1867; New York Times, April 19, 1867.

18. Julie Saville, "A Measure of Freedom: From Slave to Wage Laborer in South Carolina, 1860-1868” (Ph.D diss., Yale University, 1986), 273.

19. Richmond Whig, April 1, 1867. 
his heart even while I am talking with you here to-night. [Amen.] Show

him the error of his ways. Have mercy upon our 'Moses,' [Sarcastic.

Great laughter and amens.] who, like Esau, has sold his birthright for a

morsel of pottage - took us in the wilderness and left us there. Come down upon him, oh Lord, with thy blessing. God bless us in our meeting to-night, and help us in what we do. God forbid that we should choose any Conservative that has the spirit of the devil in his heart, and whose feet take hold on hell. God bless our friend-true and tried-Mr. Hunnicut, who has stood a great many sorrows and I think he can stand a great many more. [Laughter.] Bless our judge, Mr. Underwood, who is down here among us, and don't let anything harm a hair of his head. ${ }^{20}$

What the Whig and the Dispatch captured was a political culture in which the wide range of institutional and noninstitutional resources of individuals and the community as a whole became the basis for defining, claiming and securing freedom in post-emancipation Richmond. The church provided more than physical space, financial resources and a communication network; it also provided a cultural base that validated emotion and experience as ways of knowing, and drew on a collective call and response, encouraging the active participation of all. $^{21}$

Virginia's rejection of the Fourteenth Amendment brought the state under the Reconstruction Act of 1867; a constitutional convention became prerequisite for full restoration to the Union. Black men, enfranchised for the delegate selection and ratification ballots, were to have their first opportunity to engage in the

20. Richmond Dispatch, October 5, 1867.

21. Aldon Morris makes a similar argument regarding the church and the modern civil rights movement, emphasizing the ways in which the church served as a physical, financial and cultural resource, with its sermons, songs, testimonies and prayers becoming political resources in the mobilization of participants and in the construction and communication of political ideology. The Origins of the Civil Rights Movement: Black Communities Organizing for Change (New York: Free Press, 1984). See also, Robin D. G. Kelley, "Comrades, Praise Gawd for Lenin and Them!': Ideology and Culture Among Black Communists in Alabama, 1930-1935," Science and Society 52, 1 (Spring 1988): 59-82; Brenda McCallum, "Songs of Work and Songs of Worship: Sanctifying Black Unionism in the Southern City of Steel," New York Folklore.14, $1 \& 2$ (1988): 9-33. For an argument that eliminating emotions and aesthetics from acceptable forms of public discourse becomes a means to eliminate particular groups of people from active participation in public life, see Iris Marion Young, "Impartiality and the Civic Public: Some Implications of Feminist Critiques of Moral and Political Theory," in Feminism as Critique: On the Politics of Gender, eds. Seyla Benhabib and Drucilla Cornell (Minneapolis: University of Minnesota, 1987), 56-76. 
political parties and legislative chambers of the state. The struggles in which they had engaged in the two years since emancipation influenced the manner of black Richmonders' initial participation in the formal political arena of conventions and voting. On August 1, 1867, the day the Republican state convention opened in Richmond to adopt a platform for the upcoming state constitutional convention, thousands of African American men, women and children absented themselves from their employment and joined the delegates at the convention site, First African Baptist Church. ${ }^{22}$ Tobacco factories, lacking a major portion of their workers, were forced to close for the day.

This pattern persisted whenever a major issue came before the state and city Republican conventions held during the summer and fall of 1867 , or the state constitutional convention which convened in Richmond from December 1867 to March 1868. A New York Times reporter estimated that "the entire colored population of Richmond" attended the October 1867 local Republican convention where delegates to the state constitutional convention were nominated. Noting that female domestic servants were a large portion of those in attendance, the correspondent reported: "as is usual on such occasions, families which employ servants were forced to cook their own dinners, or content themselves with a cold lunch. Not only had Sambo gone to the Convention, but Dinah was there also."23

These men and women did not absent themselves from work just to be onlookers at the proceedings, but to be active participants. They assumed as equal a

22. The following discussion of collective enfranchisement as the basis for black women's political activism in the post-Civil War era is drawn from Elsa Barkley Brown, "To Catch the Vision of Freedom: Reconstructing Southern Black Women's Political History, 1865-1880, "in To Be a Citizen, eds. Arlene Avakian, Joyce Berkman, John Bracey, Bettye Collier-Thomas, and Ann Gordon (Amherst: University of Massachusetts Press, forthcoming).

23. Richmond Dispatch, August 1, 2, September 30, October 9, 1867; New York Times, August 1, 2, 6, October 18, 1867. My discussion of these events follows closely Peter J. Rachleff, Black Labor in the South: Richmond, Virginia, 1865-1890 (Philadelphia: Temple University Press, 1984), 45-46. See also Richard L. Morton, The Negro in Virginia Politics, 1865-1902, Publications of the University of Virginia Phelps-Stokes Fellowship Papers Number Four (Charlottesville: University of Virginia Press, 1919), 40-43. Similar reports issued from other areas throughout the South, causing one chronicler to report that "the Southern ballot-box" was as much "the vexation of housekeepers" as it was of farmers, businessmen, statesmen or others: "Elections were preceded by political meetings, often incendiary in character, which all one's servants must attend." Election day itself could also be a problem. As one Tennessean reported in 1867, "Negro women went [to the polls], too; my wife was her own cook and chambermaid," Myrta Lockett Avary, Dixie After the War: An Exposition of Social Conditions Existing in the South, During the Twelve Years Succeeding the Fall of Richmond (New York: Doubleday, Page and Co., 1906; reprint, New York: Negro Universities Press, 1969), 282-284. See also, Susan Bradford Eppes for similar occurrences in Florida, Through Some Eventful Years ([1926] reprint ed., Gainesville: University of Florida Press, 1968). 
right to be present and participate as the delegates themselves, a fact they made

abundantly clear at the August 1867 Republican state convention. Having begun to arrive four hours before the opening session, African American men and women had filled the meeting place long before the delegates arrived. Having showed up to speak for themselves, they did not assume delegates had priority in discussion or in seating. Disgusted at the scene, as well as unable to find a seat, the conservative white Republican delegates removed to the Capitol Square to convene an outdoor session. That was quite acceptable to the several thousand additional African American men and women who, unable to squeeze into the church, were now still able to participate in the important discussions and to vote down the proposals of the conservative faction. ${ }^{24}$

Black men, women and children were also active participants throughout the state constitutional convention. A New York Times reporter commented on the tendency for the galleries to be crowded "with the 'unprivileged,' and altogether black." At issue was not just these men and women's presence but also their behavior. White women, for example, certainly on occasion sat in the convention's gallery as visitors silently observing the proceedings; these African Americans, however, participated from the gallery, loudly engaging in the debates. At points of heated controversy, black delegates turned to the crowds as they made their addresses on the convention floor, obviously soliciting and relying upon mass participation. Outside the convention hours, mass meetings were held to discuss and vote on the major issues. At these gatherings vote was either by voice or rising and men, women and children voted. These meetings were not mock assemblies; they were important gatherings at which the community made plans for freedom. The most radical black Republican faction argued that the major convention issues should actually be settled at these mass meetings with delegates merely casting the community's vote on the convention floor. Though this did not occur, black delegates were no doubt influenced by both the mass meetings and the African American presence in the galleries, both of which included women. ${ }^{25}$

24. Richmond Dispatch, August 1, 2, 1867; New York Times, August 2, 6, 1867; see also Rachleff, Black Labor in the South, 45; Morton, Negro in Virginia Politics, 40-43.

25. The October 1867 city Republican ward meetings and nominating convention adopted the practice common in the black community's mass meetings: a voice or standing vote which enfranchised men, women, and children. See, for example, the October eighth Second Ward meeting for delegate selection: "All who favored Mr. Washburne were first requested to rise, and forty were found on the floor, including women." Richmond Dispatch, September 20, October 9, 1867; January 2, 4, 14, 23, 24, February 15, 25, April 3, 8, 25, 1868; New York Times, August 6, October 15, 18, 1867; January 11, 1868; Rachleff, Black Labor in the South, 45-49; Avary, Dixie After the War, 229-231, 254. 
Black Richmonders were operating in two separate political arenas: an internal one and an external one. While these arenas were related, they each proceeded from different assumptions, had different purposes, and therefore operated according to different rules. Within the internal political process women were enfranchised and participated in all public forums - the parades, rallies, mass meetings and the conventions themselves. ${ }^{26}$ Richmond was not atypical in this regard. ${ }^{27}$

The issue of children's participation is an interesting one, suggestive of the means by which personal experience rather than societal norms shaped ex-slaves' vision of politics. A similarly telling example was in the initial proposal of the African National Congress that the new South African constitution set the voting age at fourteen, a testament to those young people, as those in Soweto, who experienced the ravages of apartheid and whose fight against it helped bring about the political negotiations to secure African political rights and self-determination.

26. Compare black women's active participation in Richmond's formal politics-internal and external-in the first decades after the Civil War to Michael McGerr's assessment that nineteenthcentury "women were allowed into the male political realm only to play typical feminine roles-to cook, sew, and cheer for men and to symbolize virtue and beauty. Men denied women the central experiences of the popular style: not only the ballot but also the experience of mass mobilization." McGerr's analysis fails to acknowledge the racial basis of his study, i.e., it is an assessment of white women's political participation, Michael McGerr, "Political Style and Women's Power, 1830-1930," Journal of American History 77 (December 1990): 864-885, esp. 867. My analysis also differs substantially from Mary P. Ryan, Women in Public. Ryan gives only cursory attention to African Americans but finds black women's political expression in the Civil War and Reconstruction eras restricted "with particular severity" and "buried beneath the surface of the public sphere," see, 146147, 156, passim.

27. For women's participation in political parades in Louisville, Kentucky, Mobile, Alabama, and Charleston, South Carolina, see Herbert G. Gutman, The Black Family in Slavery and Freedom, 380; Liberator, July 21, 1865 and New York Daily Tribune, April 4, 1865, both reprinted in The Trouble They Seen: Black People Tell the Story of Reconstruction, ed. Dorothy Sterling (Garden City, New York: Doubleday, 1976), 2-4. In other areas of Virginia besides Richmond and in South Carolina and Louisiana men and women participated in the political meetings. See, for example, Vincent Harding, There Is A River: The Black Struggle for Freedom in America (New York: Harcourt Brace Jovanovich, 1981), 294-297; Rupert Sargent Holland, ed., Letters and Diary of Laura M. Towne Written from the Sea Islands of South Carolina 1862-1884 (Cambridge: Riverside Press, 1912; reprint ed., New York: Negro Universities Press, 1969), 183; Testimony of John H. Burch given before a Senate committee appointed to investigate the exodus of black men and women from Louisiana, Senate Report 693, 46th Congress, 2nd Session, part 2, 232-233 reprinted in $A$ Documentary History of the Negro People in the United States, 2 vols., ed. Herbert Apetheker (New York: Citadel Press, 1951), 2: 721-722; Thomas Holt, Black Over White: Negro Political Leadership in South Carolina during Reconstruction (Urbana: University of Illinois Press, 1977), 34-35. Graphic artists recognized the participation of women as a regular feature of parades, mass meetings, and conventions as evidenced by their illustrations. See "The Celebration of Emancipation Day in Charleston" from Leslie's Illustrated Newspaper reprinted in Francis Butler Simkins and Robert Hilliard Woody, South Carolina During Reconstruction (Chapel Hill: University of North Carolina Press, 1932; reprint ed., Gloucester, Mass.: Peter Smith, 1966), facing 364; "Electioneering at the South," Harper's Weekly, July 25, 1868 reprinted in Foner, Reconstruction, fol. 386; "Colored People's Convention in Session" reprinted in Sterling, The Trouble They Seen, 65. 
It was the state constitutional convention, however, which would decide African American women's and men's status in the political process external to the African American community. When the Virginia convention began its deliberation regarding the franchise, Thomas Bayne, a black delegate from Norfolk, argued the inherent link between freedom and suffrage, and contended that those who opposed universal suffrage were actually opposing the freedom of African American people. In rejoinder, E. L. Gibson, a Conservative white delegate, enunciated several principles of republican representative government. Contending that "a man might be free and still not have the right to vote," Gibson explained the fallacy of assuming that this civil right was an inherent corollary to freedom: if the right were inherent then it would belong to both sexes and to all from "the first moment of existence" and to foreigners immediately. This was "an absurdity too egregious to be contemplated." 28 And yet, this "absurd" notion of political rights was what was in practice in the Richmond black community males and females voted without regard to age, the thousands of rural migrants who came into Richmond suffered no waiting period but immediately possessed the full rights of the community. What was absurd to Gibson and most white men - Republican or Democrat - was obviously quite rational to many black Richmonders. Two very different conceptions of freedom and public participation in the political process were in place.

In the end only men obtained the legal franchise. The impact of this decision is neither inconsequential nor fully definitive. African American women were by law excluded from the formal political arena external to their community. Yet this does not mean that they were not active in that arena; witness Richmond women's participation in the Republican and the constitutional conventions. Southern black men and women debated the issue of women's suffrage in both the external and internal political arenas. In Nansemond County, Virginia, for example, the mass meetings resolved that women should be granted the legal franchise; in Richmond, while a number of participants in a mass meeting supported female suffrage, the majority opinion swung against it. ${ }^{29}$ But the meaning of that decision was not as straightforward as it may seem. The debate as to whether women should be given the vote in the external political arena occurred in internal political arena mass meetings where women participated and voted

28. New York Times, January 11, 22, 1868; The Debates and Proceedings of the Constitutional Convention of the State of Virginia, Assembled at the City of Richmond (Richmond, 1868), 505507, 524-527.

29. Richmond Dispatch, June 18, 1867; Rachleff, Black Labor in the South, 48. 
not just before and during, but also after the negative decision regarding legal enfranchisement. This maintained the status quo in the external community; ironically enough, the status quo in the internal community was maintained as wellwomen continued to have the vote. African American men and women clearly operated within two distinct political systems.

Focusing on formal disfranchisement obscures women's continued participation in the external political arena. In Richmond and throughout the South exclusion from legal enfranchisement did not prevent African American women from shaping the vote and the political decisions. Throughout the late $1860 \mathrm{~s}$ and $1870 \mathrm{~s}$ women continued to participate in political meetings in large numbers and to organize political societies. Some like the Rising Daughters of Liberty and the Daughters of the Union Victory in Richmond or the United Daughters of Liberty organized by coal miners' wives living outside Manchester had all-female memberships. Others, like the 2000 member National Political Aid Society, the Union League of Richmond and the Union Equal Rights League of Manchester had male and female members. Even though white Republicans made efforts to exclude them from further participation in political meetings by the late $1860 \mathrm{~s}$, African American women in Virginia, South Carolina, Louisiana and elsewhere were still attending these meetings in the 1870 s.

Women's presence at these meetings was anything but passive. In the violent political atmosphere of the last years of Reconstruction, they had an especially important and dangerous role. In South Carolina, for example, while the men participated in the meeting, the women guarded the guns - thus serving in part as the protectors of the meeting. For those women and men who lived in outlying areas of Richmond and attended outdoor meetings, political participation was a particularly dangerous matter, a fact they clearly recognized. Meetings were guarded by posted sentinels with guns who questioned the intent of any suspicious people, usually white men, coming to the meeting. A reporter for the Richmond Daily Dispatch described one such encounter when he attempted to cover a political meeting of fifty women and twenty-five men. ${ }^{30}$

Women as well as men took election day off from work and went to the polls. Fraud, intimidation and violence became the order of election days. White newspapers and politicians threatened loss of jobs, homes and lives. AfroRichmonders countered with a group presence. Often even those living within

30. Rachleff, Black Labor in the South, 31-32; Richmond Daily Dispatch, May 10, 1867; New Nation, November 22, 29, December 6, 1866; Holt, Black Over White, 35; Avary, Dixie After the War. 
the city and short distances from the polling places went early, even the night

before, and camped out at the polls, hoping that their early presence would require the acceptance of their vote and that the group presence would provide protection from violence and intimidation. In the highly charged political atmosphere of to Freedom late-nineteenth century Richmond it was no small matter for these women and men to participate in political meetings and show up at the election sites. The reasons for the group presence at the polls were varied. African American women in Virginia, Mississippi, South Carolina and elsewhere understood themselves to have a vital stake in African American men's franchise. The fact that only men had been granted the vote did not at all mean that only men should exercise the vote. Women throughout the South initiated sanctions against men who voted Democratic; some went along to the polls to insure a properly cast ballot. As increasing white fraud made black men's voting more difficult, early arrival at the polls was partly intended to counter such efforts.

Although election days in Richmond were not as violent as they were elsewhere throughout Virginia and other parts of the South, guns were used to intimidate and defraud. It is also probable that in Richmond, as elsewhere throughout the South, when black men went to camp out overnight at the polls, households feared leaving women and children unprotected at home. Thus the women's presence, just as the group presence of the men, may have been a sign of the need for collective protection. If Richmond women were at all like their sisters in South Carolina and Danville, they may have carried weapons with them - to protect themselves and/or help protect the male voters. ${ }^{31}$ Women and children's presence reflects their excitement about the franchise but also their understanding of the dangers involved in voting. The necessity for a group presence at the polls reinforced the sense of collective enfranchisement. Women's presence at the polls was both a negative sanction and a positive expression of the degree to which they understood the men's franchise to be a new political opportunity for themselves as well as their children.

In the dangerous political atmosphere of the late-nineteenth century, the vote took on a sacred and collective character. Black men and women in Richmond, as throughout the South, initiated sanctions against those black men perceived

31. Barkley Brown, "To Catch the Vision of Freedom"; Richmond Enquirer, October 22, 1867; Richmond Whig, October 19, 1867; Robert E. Martin, "Negro Disfranchisement in Virginia," The Howard University Studies in the Social Sciences, I (Washington, D. C., 1938): 65-79; Richmond Afro-American, December 2, 1962; Mrs. Violet Keeling's testimony before Senate investigating committee, February 18, 1884, Senate Report No. 579, 48th Congress, 1st Session, reprinted in Aptheker, Documentary History, 2: 739-741. 

Democrats were subject to the severest exclusion: disciplined within or quite often expelled from their churches and mutual benefit societies; denied board and lodging with black families. Additionally, mobs jeered, jostled and sometimes beat black Democrats or rescued those who were arrested for such acts. Women were often reported to be in the forefront of this activity. Similarly, black women were said to have "exercised a positive influence upon some men who were inclined to hesitate or be indifferent" during the early 1880s Readjuster campaigns. ${ }^{32}$

All of this suggests that African American women and men understood the vote as a collective, not an individual possession; and furthermore, that African American women, unable to cast a separate vote, viewed African American men's vote as equally theirs. They believed that franchise should be cast in the best interest of both. This is not the nineteenth century patriarchal notion that men voted on behalf of their wives and children. By that assumption women had no individual wills; rather men operated in women's best interest because women were assumed to have no right of input. African American women assumed the political rights that came with being a member of the community even though they were denied the political rights they thought should come with being citizens of the state.

32. Barkley Brown, “To Catch the Vision of Freedom"; Howard N. Rabinowitz, Race Relations in the Urban South, 1865-1880 (New York: Oxford University Press, 1978), 222; Alrutheus Ambush Taylor, The Negro in the Reconstruction of Virginia (Washington, D.C.: The Association for the Study of Negro Life and History, 1926), 181, 269; Michael B. Chesson, "Richmond's Black Councilmen, 1871-96," in Southern Black Leaders of the Reconstruction Era, ed. Howard N. Rabinowitz (Urbana: University of Illinois Press, 1982), 219n; Peter J. Rachleff, "Black, White and Gray: Working-Class Activism in Richmond, Virginia, 1865-1890" (Ph.D. diss., University of Pittsburgh, 1981), 473, 488n; Richmond Dispatch, October 25, 26, 1872; September 14, 1874; Avary, Dixie After the War, 285-286, 347; Thomas J. Evans, Alexander Sands, N. A. Sturdivant, et al., Richmond, to Major-General Schofield, October 31, 1867, reprinted in Documents of the Constitutional Convention of the State of Virginia (Richmond: Office of the New Nation, 1867), 22-23; John H. Gilmer to Gen. Schofield reprinted in New York Times, October 30, 1867; New York Times, November 3, 1867; Wendell P. Dabney, "Rough autobiographical sketch of his boyhood years," (typescript, n.d.), 98-99, microfilm copy in Wendell P. Dabney Papers, Cincinnati Historical Society, Cincinnati, Ohio; Proceedings before Military Commissioner, City of Richmond, 26 October 1867 in the case of Winston Jackson filed as G-423 1867 Letters Received, ser. 5068, 1st Reconstruction Military District, Records of the U.S. Army Continental Commands, Record Group 393, Pt. 1, National Archives [SS-1049] (bracketed numbers refer to files in the Freedmen and Southern Society Project, University of Maryland; I thank Leslie S. Rowland, project director, for facilitating my access to these files); George F. Bragg, Jr., Baltimore, Maryland, to Dr. Woodson, August 26, 1926, reprinted in "Communications," Journal of Negro History XI (1926), 677. 
To justify their political participation Richmond and other southern black women in the immediate post-Civil War period did not need to rely on arguments of superior female morality or public motherhood. Their own cultural, economic and political traditions provided rationale enough. An understanding of collective autonomy was the basis on which African Americans reconstructed families, developed communal institutions, constructed schools and engaged in formal politics after emancipation. The participation of women and children in the external and internal political arenas was part of a larger political worldview of exslaves and free men and women, a worldview fundamentally shaped by an understanding that freedom, in reality, would accrue to each of them individually only when it was acquired by all of them collectively. Such a worldview contrasted sharply with the "possessive individualism" of liberal democracy. ${ }^{33}$ This sense of suffrage as a collective, not an individual possession was the foundation for much of African American women's political activities in the post-Civil War era. ${ }^{34}$ Within these understandings the boundary lines between men's and women's political behavior were less clearly drawn and active participation in the political arenas - internal or external - seldom required a retreat into womanhood or manhood as its justification.

Even in the organization of militia units, post-emancipation black Richmonders, at least for a time, rejected the liberal bourgeois ideal of a solely male civic domain. By 1886 black men had organized three militia companies. By the late 1870 s black women had also organized a militia company, although apparently only for ceremonial purposes; it reportedly was active only before and during emancipation celebrations. Its members conducted preparatory drills on Broad Street, one of Richmond's main thoroughfares. Frank Anthony, the man who prepared and drilled the women's company, demanded military precision and observance of regular military commands. ${ }^{35}$ Unlike the men participating in the

33. See Thomas C. Holt, “AAn Empire over the Mind': Emancipation, Race, and Ideology in the British West Indies and the American South," in Region, Race, and Reconstruction: Essays in Honor of C. Vann Woodward, ed. J. Morgan Kousser and James M. McPherson (New York: Oxford University Press, 1982), 283-314; also David Montgomery, The American Civil War and the Meanings of Freedom: An Inaugural Lecture delivered before the University of Oxford on 24 February 1987 (Oxford: Clarendon Press, 1987), 11-13.

34. This is not to suggest that African American women did not desire the vote nor that they did not often disagree with the actions taken by some black men. One should, however, be careful about imposing presentist notions of gender equality on these women. Clearly for them the question was not an abstract notion of individual gender equality but rather one of community. That such a vision might become over time a lead into a patriarchal conception of gender roles is not a reason to dismiss the equity of its inception.

35. Dabney, "Rough autobiographical sketch," 17-18. 
militias, who came from working-class, artisan, business and professional backgrounds, the women were probably working-class. Although they served no self-defense role, their drilling in Richmond streets and marching in parades challenged ideas and assumptions about appropriate public behavior held by both white southerners and white Unionists. The women's unit not only challenged, as did the men's, the idea of black subservience, but also suggested wholly new forms and meanings of respectable female behavior. There is no evidence concerning how long this women's unit survived or the causes of its demise. We can speculate that, besides horrifying whites, such a unit may have also become unacceptable to a number of black Richmonders. Increasingly, concerns about respectable behavior were connected to the public behavior of the working class and of women. This black women's militia, however, suggests the fluidity of gender notions in the early years of emancipation. The brevity of its appearance suggests how questions of public behavior became integral within black Richmond, just as they had been within the larger society. Yet for a time the actions of these women declared that perhaps no area of political participation or public ceremony was strictly a male domain.

\section{Renegotiating Public Life}

The 1880 First African women's petition followed three contentious church meetings, some lasting until two or three o'clock in the morning, at which the congregants considered dismissing and/or excluding the pastor, the Reverend James $\mathrm{H}$. Holmes. This discussion was initiated at an April fifth meeting where two women were charged with fighting about the pastor. The April sixth meeting considered charges of "unchristian conduct" on the part of Holmes; those men present voted to exclude Holmes. A meeting on April eleventh endorsed a protest signed by all but two of the deacons against the earlier proceedings. The protest charged the anti-Holmes faction with trying to "dispose of the deacons, take charge of prayer meetings, the Sunday school and revolutionize things generally." The discussions which ensued over the next two months split the congregation; the May and June church business meetings were "disorderly" and "boisterous." Holmes and the deacons called in the mayor, city court judge, and chief of police to support the pastor and the police to remove or arrest those members of the congregation designated as "rebellious." After the anti-Holmes faction was removed from the church, the June meeting expelled forty-six men for "rebelliously attempting to overthrow and seize upon the church government." It also excluded the two women initially charged, one for fighting and the other for tattling; 

the controversy more than two months earlier. ${ }^{36}$

First African's records do not adequately reveal the nature of gender relations within the church in the late 1860 s and $1870 \mathrm{~s}$. We do know that the pre-Civil War sex-segregated seating patterns were abandoned by Richmond black Baptist churches immediately after the Civil War and that by the late 1860 s women "not only had a voice, but voted in the business meetings" of Ebenezer Baptist Church. ${ }^{37}$ Women who voted in political meetings held in First African in the 1860s and 1870s may have carried this participation over to church business meetings. Often in the immediate post-Civil War period, business and political meetings were not clearly distinguishable.

The petition of the women of First African makes clear, however, that by the early $1880 \mathrm{~s}$, while women attended and apparently participated in church meetings, the men had "adopted a law in the church that the business must be done by the male members." Whether Margaret Osborne, Jane Green, and others thought that their voices and interests were being inadequately represented, even ignored by the deacons, or wanted to add their voices to those, including the deacons, who were struggling to retain Holmes and control of First African, these women understood that they would have to defend their own rights. The women argued their right to decide on the pastor, justifying their petition by both their work on behalf of the church and the importance of their economic support to the church's ongoing activities and to the pastor's salary. Not until after the matter of Holmes's exclusion was settled were the petitioners granted their request. Since they apparently remained within First African, the petitioners' organization probably indicates that they were not among those dissatisfied with Holmes. It does suggest, however, their dissatisfaction with church procedure and the place of women in church polity. Still, the petition was conservative and

36. FABC, II, April 5, 6, 11, May 3, June 27, 1880.

37. First African minutes for 1841-1859 and 1875-1930, are available at First African and on microfilm in Archives, Virginia State Library. The Civil War and immediate post-emancipation minutes apparently have not survived. Peter Randolph, who came to Richmond from Massachusetts within weeks of emancipation and became the first black man elected pastor of Ebenezer Baptist, attributed both the change in seating patterns and the formal inclusion of women as voters in church business meetings to his own progressivism. Whether or not he initiated such measures, it is unlikely either change would have been effected without wide acceptance within the congregation. Randolph, From Slave Cabin to Pulpit, 89. 
the women denied any intention to demand full voting rights in church matters. The petition was not taken as a challenge to church authority, as were the actions of the anti-Holmes faction. When brought up for a vote in the June meeting, the women's petition was adopted by a vote of 413 to $16 . .^{38}$

The women's petition and the vote in favor of it suggest the tenuous and ambiguous position that women had come to occupy both within First African and within the internal political arena more generally. They participated actively in church meetings but the authority for that participation and the question of limiting women's role resurfaced throughout the late-nineteenth century. In the 1890s the women of First African would again have to demand their rights, this time against challenges to their very presence at church meetings, when a deacon sought to prohibit women from even attending First African business meetings. The women protested and the church responded quickly by requiring the deacon to apologize to the women and assure them that they were welcome at the meetings. The degree of women's participation and decision-making powers, however, remained ambiguous.

In 1901-1902 during another crisis period in First African, a number of men sought to blame the problems on women. John Mitchell, Jr., a member of First African and editor of the Richmond Planet, cited the active participation of women ("ladies who knew nothing of the machinery at work or the deep laid plans on foot") and children ("Sunday School scholars from 8 years of age upward") in church affairs, suggesting that they did not comprehend the proceedings and had been easily misled or manipulated by male factions. Deacon J. C. Farley cited women's active participation in church meetings as the problem, reminding the congregation that "it was the rule of the church" that women were only allowed to vote on the pastor but had extended their participation far past that. And the new minister, the Reverend W. T. Johnson, admonished the women, saying that "the brethren could almost fight in the church meeting and when they went out they would shake hands and laugh and talk. But the sisters would talk about it going up Broad St. and everybody would know what they had done." First African women rejected these assessments of their church's problems. A significant number walked out rather than have their participation censured; those who remained reportedly refused to be silent but continually "talked out in the meeting." Sister Margaret Hewlett later sought out the editor of the Richmond Planet to voice her opposition to the men's denunciation of women's roles and to make clear that

38. FABC, II, June 27, 1880. 
the women thought the church's problems lay in the male leadership, saying specifically "the deacons were the cause of all the trouble anyway." 39

In the early 1890s the Virginia Baptist publicized its belief that women, in exceeding their proper places in the church by attempting to preach, and in the community by their "deplorable" efforts to "exercise the right of suffrage," would lose their "womanliness." 40 The complexity of gender relations within the African American community was such that at the same time First African was debating women's attendance at church meetings and the Virginia Baptist was advocating a severely restricted women's role, other women such as Alice Kemp were known throughout the community as the authors of prominent male ministers' sermons and women such as the Reverend Mrs. Carter were establishing their reputations as "soul-stirring" preachers. The Richmond Planet reported these women's activities without fanfare, as if they were commonplace. The debate over women's roles also had become commonplace. The Reverend Anthony Binga, pastor of First Baptist (Manchester), noted the debate in his sermon on Church Polity; Binga supported women teaching Sunday School, participating in prayer-meetings and voting "on any subject pertaining to the interest of the church" including the pastor; but he interpreted the Bible as forbidding women "throwing off that modesty that should adorn her sex, and taking man's place in the pulpit." The subject received community-wide attention in June 1895 when Ebenezer Baptist Church staged a debate between the ministers of Second Baptist (Manchester) and Mount Carmel, judged by other ministers from Fourth Baptist, First African, First Baptist (Manchester) and others on the subject, "Resolved that a woman has every right and privilege that a man has in the christian church." 41

39. FABC, III November 7, 20, 1899; Richmond Planet, July 6, 20, August 10, 31, 1901, March 8, 15, 1902. Similar debates must have occurred in Ebenezer Baptist Church as well. In approving the conduct of business at Ebenezer, Mitchell noted that "only the male members were permitted to vote" on the appointment of a new pastor, Richmond Planet, September 14, 1901. These debates over gender roles within black churches occurred on congregational and denominational levels. For studies which examine these debates at the state and/or national level, see, for example, Higginbotham, Righteous Discontent; Glenda Gilmore, "Gender and Jim Crow: Women and the Politics of White Supremacy in North Carolina, 1896-1920" (Ph.D. diss., University of North Carolina, Chapel Hill, 1992); Cheryl Townsend Gilkes, “'Together and in Harness': Women's Traditions in the Sanctified Church," Signs: Journal of Women in Culture and Society 10 (Summer 1985): 678-699.

40. Virginia Baptist cited in Woman's Era, 1 (September 1894), 8.

41. Richmond Planet, July 26, 1890; June 8, 1895; September 17, 24, November 19, 1898; September 9, 1899; Anthony Binga, Jr., Sermons on Several Occasions, I (Richmond, 1889), 9799. Both Kemp and Carter were Baptist. A few women also conducted services in the Methodist church. Evangelist Annie E. Brown, for example, conducted two weeks of revival services at Leigh Street Methodist Episcopal Church in 1900, Richmond Planet, April 28, 1900. Even when one 
The debates within First African and other churches over women's roles were part of a series of political struggles within black Richmond in the late-nineteenth and early-twentieth centuries. As formal political gains, initially secured, began to recede and economic promise became less certain and less surely tied to political advancement, the political struggles over relationships between the working-class and the newly emergent middle-class, between men and women, between literate and nonliterate, increasingly became issues among Afro-Richmonders. Briefly examining how the sites of public discourse changed and how discussions regarding qualifications for and nature of individual participation developed suggests the degree to which debates over space and relationships represented important changes in many black Richmonders' assumptions about freedom itself.

The authority of the church in personal and civil matters decreased over the late-nineteenth and early-twentieth centuries. The church quietly acknowledged these changes without directly confronting the issue of its changed authority. The use of civil authorities to resolve the church dispute, especially since individual members continued to face censure if they relied on civil rather than church sanctions in a dispute with another member, suggests the degree to which First African tried to maintain its traditional authority over its members while acknowledging the limitations of its powers. First African turned outside not only itself but also the black community by inviting the intervention of the mayor, police chief and judge..$^{42}$ The decreasing authority of the church, however, accompanied a shrinking sphere of influence and activity for the church and the development of secular institutions and structures to take over, compete for, or share functions traditionally connected to the church as institution and structure. The changing church axis suggests important developments in the structures, nature and understandings of community in black Richmond.

"female preacher . . . took up station" outside a Manchester barbershop and preached against the male members, claiming they were "leading the young down to perdition," the Planet's Manchester correspondent did not denounce her right to preach but rather suggested that if she "is called to preach the gospel, and is sanctified, as some say, why not organize a church of sanctification," rather than stand on street corners issuing "broad and uncalled for" attacks upon other ministers, Richmond Planet, December 12, 1896.

42. In July 1880 a council representing nine Richmond black Baptist churches censured First African for having called the police. "The First African Baptist Church, Richmond, Virginia, to the Messengers \& Churches in General Ecclesiastical Council Assembled,” in FABC, II, following April 3, 1881 minutes. For late-nineteenth century disciplinary procedures with regard to members who got civil warrants against other members, see for example, FABC, II, January 7, October 6, 1884; February 3, 1890. 
After the Reverend James Holmes and the deacons of First African survived the 1880 challenge to their leadership, one of their first actions was to establish a regulation that church business meetings be closed to all but members. They had argued that it was outside agitators who had instigated and sustained the disorder and opposition. While this reflects concerns about internal church business, the closing off of the church was reflected in other central ways which potentially had more far-reaching consequences, and suggests the particularization of interests, concerns and functions of internal community institutions, and the changed nature of internal community politics. Having completed, at considerable expense, their new edifice, First African worried about avoiding damage and excess wear and tear. In November 1882 the church adopted regulations designed to eliminate the crowds of people attending weddings in the church by requiring guest lists and tickets, and to deny entirely the use of the main auditorium with the largest capacity for "programmes, closing of public schools, political meetings or feasts." In February 1883 when the Acme Lyceum requested use of the main auditorium for a lecture by Frederick Douglass, the church, following its new regulations, refused to grant the request, although it did offer as substitute the use of its smaller lecture room. That same year it denied the use of the church for the Colored High and Normal closing. The paucity of facilities available to black Richmonders meant that these activities now had to be held in much smaller facilities and the possibilities for the large mass meetings which First African had previously hosted were now reduced. Political meetings and other activities moved to other, smaller church sites or to some of the new halls being erected by some of the societies and businessmen. The latter, however, were more expensive to obtain since their rental was a major source of revenue for the group or individual owner; it also often particularized the meeting or occasion to a specific segment of the community. Without the large facility of First African, graduations and school closings could no longer be the traditional community-wide mass celebrations. Denied the use of First African and barred from the Richmond Theatre where the white high school students had their graduation, the 1883 Colored High and Normal graduation class held their exercises in a small classroom where very few could attend..$^{43}$

43. FABC, II, June 27, November 6, 1882; February 5, April 2, 1883. Wendell P. Dabney, a member of that 1883 graduating class, remembered the students as having met in early June and "determined not to go to any church. That we would go to the Richmond Theatre or no where." He calls this "the first school strike by Negro pupils on record in the Unites States!" First African had, however, already denied the use of its facilities because of its new regulation. There is some evidence that, subsequent to the students' action, other black churches may have supported the young people by denying their facilities as well. Dabney, "Rough autobiographical sketch of his boyhood years," 
First African did not initiate and was not singly responsible for the changing nature of Republican Party participation, but its actions reinforced the narrower sense of party politics that white Republicans had already tried to enforce. Disturbed at black influence over Republican meetings, beginning in 1870 white Republican officials had taken steps to limit popular participation and influence in party deliberations. First they moved the party conventions from First African to the United States courtroom, a facility which held many fewer people and was removed from the black community; then they closed the gallery, thus allowing none but official delegates to attend and participate. In such a setting they were able to adopt a more conservative platform. Black Republicans had continued, however, to hold mass meetings, often when dissatisfied with the official Republican deliberations. When they were dissatisfied with Republican nominees for municipal office that came from the 1870 closed party convention, for example, black Republicans agreed to convene their own sessions and make their own nominations. ${ }^{44}$

In increasingly delimiting the church's use, distinguishing more clearly between sacred and secular activities as when it began to disallow certain kinds of entertainments in its facilities or on its behalf, and attempting to reserve the church for what was now designated as the "sacred," First African contributed to the increasing segmentation of black Richmond. ${ }^{45}$ With the loss of the largest capacity structure some black Richmonders recognized the need to reestablish a community space. Edward A. Randolph, founder and first editor of the Richmond Planet, used Acme Literary Association meetings to argue regularly throughout 1883 and 1884 for the construction of a hall, a public meeting place within the community. His call was reinforced when the Choral Association was denied use of the Richmond Theatre and had to have its production in a small mutual benefit society hall, an inadequate facility for such a production. The construction of a large auditorium on the top floor of the Grand Fountain, United Order of True Reformers' bank and office building when it opened in 1890 was an effort to provide that space. It could hold larger gatherings than the other halls and most churches but still had only a small percentage of the seating capacity of

107-109; Wendell P. Dabney, Maggie L. Walker and the I. O. of Saint Luke: The Woman and Her Work (Cincinnati: Dabney Publishing Co., 1927), 32-33. New York Globe, June 23, 1883.

44. Rachleff, "Black, White, and Gray," 307-309.

45. See, for example, the discussion of the reconfiguration of leisure space, including the barring of cakewalks and other dancing from the church, in Elsa Barkley Brown and Gregg D. Kimball, "Mapping the Terrain of Black Richmond," Journal of Urban History (forthcoming). 
First African. ${ }^{46}$ A mass meeting on the scale common in the 1860 s and 1870 s could be held only outside the community and the facilities for such were often closed to African Americans.

As political meetings moved to private halls rather than church buildings, they became less mass meetings not only in the numerical sense; they also became more gatherings of an exclusive group of party regulars. This signaled not only a change in the role of the church but also a change in the nature of politics in black Richmond. The emerging format gave business and professional men, especially, greater control over the formal political process. First African's prohibitions against mass meetings, school closings, and other programs did not last long; the need and desire of members and other Afro-Richmonders for a space which could truly contain a community-wide activity eventually led members to ignore their prohibition. But instituting the prohibition had not only significantly affected community activities in the early 1880 s; it also meant that, even after strict enforcement was curtailed, decisions about using the church for graduation exercises, political meetings and other activities were now subjects of debate. Afro-Richmonders could no longer assume the church as a community meeting place; instead they had to argue such. The church remained an important community institution, but it increasingly shared power with both civil authorities and other community institutions such as mutual benefit and fraternal societies.

The efforts by white Republican officials to limit popular decision-making and the decreased accessibility of First African as a community-wide meeting place affected a politics which had been based in mass participation. Mass meetings were still held throughout the late-nineteenth century, but they were now less regular. These changes were exacerbated by the struggle to retain the vote and office-holding and the necessity, therefore, to counter various tactics of both white Republicans and Democrats. The fraudulent tactics employed to eliminate black voters, for example, led some black Republicans, like John Mitchell, who continued to argue against literacy qualifications for voting, in the 1890 s to encourage nonliterate black men to abstain from voting. Difficulty with many of the election officials' questions and with the ballots could not only delay the line but also the nonliterate voter's rights and/or ballot would more likely be challenged.

46. New York Globe, October 1883-January 1884. Estimates of the True Reformers' auditorium's seating capacity range from 900 to 1500 to 2000 . Nearly 4000 people had been able to attend the March 1867 mass meeting held in First African in support of the Federal Sherman Bill. With their new edifices erected in 1890, Sixth Mount Zion and Sharon Baptist Churches had seating capacity of 1400 and 1200 respectively; most churches seated far fewer, Rachleff, Black Labor in the South, 40; Richmond Planet, March 14, May 31, 1890. 
Mitchell thought it important to get those least likely to be challenged or disqualified, and most capable of correctly marking the ballots, through the lines first before polls closed on them. While Mitchell argued for a temporary change in practice-not perspective - regarding the right of all to vote, his and other prominent black Republicans' prioritizing of the literate voter significantly changed the makeup of the presumed electorate.

As the divisions between black and white Republicans became deeper in the 1890s, Mitchell and other black Republicans began to hold small Republican caucuses in selected homes, in essence attempting to control ward conventions by predetermining nominees and issues. The ward conventions themselves were often held in halls rather than the larger churches. The organization in 1898 of a Central Republican League which would oversee black Republican activities through sub-Leagues in all the city's wards reinforced the narrowing party politics framework. Republican Party decision-making was now more clearly limited to Party regulars; the mass of black voters and other election activists were expected to support these channels of decision-making. ${ }^{47}$ These changes, consistent with democratic politics and republican representative government as practiced in late-nineteenth century United States, served to limit the power and influence of most black Richmonders in the electoral arena. If many black men abandoned electoral politics even before formal disfranchisement, it was in large measure due to the effectiveness of the extra-legal disfranchisement efforts of white men. The exclusion from real decision-making power within the Republican Party and, in this respect within the community, was also decisive.

The increasingly limited notion of political decision-makers which these changes encouraged is also evident in other ways. In 1896 during a factional dispute among black Republicans, John Mitchell challenged the decisions made in one meeting by noting that a substantial portion of those attending and participating were not even "legal voters," that is they were women. Although he espoused feminine dress and comportment, Mitchell supported women's rights and championed Dr. Sarah G. Jones's success as a physician as evidence of women's equality. He also endorsed women's suffrage while advising black women to understand the racism of the white women's suffrage movement and not to align themselves with it. Despite these personal convictions, Mitchell could dismiss or minimize opposing factions by a reference to the participation of women, suggesting the ways in which the

47. For information on the Central Republican League, see Richmond Planet, August-September 1898; Richmond Evening Leader, August 6, 16, 24, 27, 30, September 1, 28, October 12, 1898; Richmond Times, August 3, September 3, 11, 1898; Richmond Dispatch, September 14, 1898. 
of the ownership of the franchise had changed in the late-nineteenth century. ${ }^{48}$

Questions of qualifications for participation in the external political arena and internal community institutions were now frequent. During the conflictual 1901 business meeting at First African, for example, John Mitchell, Jr., questioned his opponents' right to participate even though they were all church members by pointing out their unfamiliarity with parliamentary procedure or their inelegant ways of speaking. The women, who were the targets of much of Mitchell's challenge, refused to accept these as criteria for their participation and even denigrated what he put forth as his formal qualifications by talking out when he got up to speak, saying derisively, "Don't he look pretty." ${ }^{\text {"9 }}$ Questions of formal education had already affected the congregation in fundamental ways, most obviously in the late-nineteenth century debate over song, a debate which represented a significant change in the basis of collective consciousness.

The antiphonal nature of the traditional church service at First African and many black churches reinforced a sense of community. The services included spontaneous verbal and nonverbal interaction between minister and prayer, speaker and congregation thus allowing for the active participation of everyone in the worship service. It was this cultural discourse that was carried over into the political meetings. One important element that bound the congregation together was song; as Lawrence Levine has noted, through their collective song churchgoers "meld[ed] individual consciousness into the group consciousness." 50 However, the practice of lining hymns which was basic to collective song was one which white visitors often referred to when they described what they perceived as the unrefined black church services. Some black churchgoers saw the elimination of this practice as part of the work of uplifting the religious style and uplifting the race. But with the elimination of this practice, those unable to read and follow the lyrics in a song book were now unable to participate, to be fully a part of the community, the collective. It was the equivalent of being deprived of a voice,

48. Richmond Planet, January 26, 1895; October 17, 1896. Similarly, when black Republican men formed the Negro Protective Association in 1898 to organize to retain their vote and political influence, one of the most controversial discussions concerned whether to allow a women's auxiliary, the main purpose of which would be to raise monies for electoral activities. Because of heated opposition the proposal was abandoned. Proceedings of the Negro Protective Association of Virginia, Held Tuesday, May 18th, 1897, in the True Reformers' Hall, Richmond, Va. .

49. Richmond Planet, July 6, 1901.

50. Lawrence Levine, Black Culture and Black Consciousness: Afro-American Folk Thought from Slavery to Freedom (New York: Oxford University Press, 1977). 

First African and pastor of Second Baptist (Manchester) as well as public school teacher, suggested such in his poem, "De Linin' Ub De Hymns":

Dar's a mighty row in Zion, an' de debbil's gittin' high,

'Twuz 'bout a berry leetle thing - de linin' ub a hymn.

De young folks say 'tain't stylish to lin' um out no mo';

Dat dey's got edikashun, an' dey wants us all to know

Dey likes to hab dar singin'-books a-holin' fore dar eyes,

An' sing de hymns right straight along 'to manshuns in de skies.'

An' ef de ol' folks will kumplain 'cause dey is ol' an' blin',

An' slabry's chain don' kep' dem back frum larnin' how to read-

Dat dey mus' take a corner seat, an' let de young folks lead.

We don' edikate our boys an' gals, an' would do de same again;

De sarmon's highfalutin', an' de church am mighty fin';

De ol'-time groans an' shouts an' moans am passin' out ub sight-

Edikashun changed all dat, an' we belebe it right,

We should serb God wid 'telligence; fur dis one thing I plead:

Jes' lebe a leetle place in church fur dem ez kin not read. ${ }^{51}$

51. Daniel Webster Davis, “De Linin' Ub De Hymns," 'Weh Down Souf and Other Poems (Cleveland: The Helman-Taylor Company, 1897), 54-56. 
The debates about women's roles in the church and in the more formal political arenas, like the debate over lining the hymns, were part of widespread discussions about the nature of community, of participation and of freedom.

From Slavery

The proliferation of scholarly works centered on the flowering of black women's political activity in the late-nineteenth and early-twentieth centuries ${ }^{52}$ has perhaps left the impression that this was the inaugural moment or even height of black women's participation in politics. Overt or not, the suggestion seems to be that black women came to political prominence as (because) black men lost political power.$^{53}$ In much of this scholarship the reasons for black women's "emergence" are usually tied to external factors. For example, the development of black women's clubs in the late-nineteenth century and their important roles in the political struggles of the twentieth century most often have been seen by historians as the result of the increasing development of such entities in the larger society and as reaction to vitriolic attacks on the morality of black women. Such a perspective explains this important political force solely in terms of external dynamics, but external factors alone cannot account for this development. ${ }^{54}$ The

52. The scholarly emphasis on this latter period is not merely a reflection of available sources. It also reflects the conceptual paradigms that have guided the investigation of black women's politics: a focus on the national level, often with minimal attention to different patterns within the North and the South; the acceptance of what Suzanne Lebsock has called the "consensus . . . that for women the standard form of political participation" in the nineteenth century "was the voluntary association"; an emphasis on autonomous women's organizations; and a focus on excavating political (and feminist) texts. This scholarly emphasis has produced a number of insightful works about the period; among them are Higginbotham, Righteous Discontent; Gilmore, "Gender and Jim Crow"; Hazel V. Carby, Reconstructing Womanhood: The Emergence of the Afro-American Woman Novelist (New York: Oxford University Press, 1987); Claudia Tate, Domestic Allegories of Political Desire: The Black Heroine's Text at the Turn of the Century (New York: Oxford University Press, 1992). Quote is from Suzanne Lebsock, "Women and American Politics, 1880-1920," in Women, Politics, and Change, eds. Louise A. Tilly and Patricia Gurin (New York: Russell Sage Foundation, 1990), 36.

53. Seeing the $1880-1920$ period as "the greatest political age for women (including black women)," Suzanne Lebsock raises the question "what does it signify" that such occurred at "the worst" age for black people; "an age of disfranchisement and increasing legal discrimination," "Women and American Politics," 59, 37. Glenda Gilmore, in an otherwise thoughtful and nuanced study, contends that black women in North Carolina gained political prominence at the turn-of-the-century as (because) black men vanished from politics - either leaving the state altogether or sequestering themselves in a nonpolitical world, "Gender and Jim Crow," chapter 5. It is an idea, however, that is often unstated but implicit in much literature which imagines black women's turn-of-the-century club movement as their initial emergence into politics. Such a narrative contributes to the fiction that black women were safer in the Jim Crow South than were black men.

54. I am indebted to Stephanie J. Shaw for making the point that it was internal community dynamics more so than external factors which gave rise to the black women's clubs in the late-nineteenth century. See, Stephanie J. Shaw, "Black Club Women and the Creation of the National Association of Colored Women," Journal of Women's History 3 (1991): 10-25. In the end, my analysis of what those internal factors were differs somewhat from Shaw's; she attributes their rise to migration and 
internal political arena, which in the immediate post-Civil War era was grounded in the notion of a collective voice which gave men, women and children a platform and allowed them all participation, came increasingly in the late-nineteenth century to be shaped by a narrowing notion of politics and appropriate political behavior.

While mass meetings continued to be held, the more regular forums for political discussions were literary societies, ward meetings, mutual benefit society and fraternal society meetings, women's clubs, labor organizations, newspapers, streetcorners, kitchens, washtubs and saloons. In the development of literary societies as a primary venue for public discussion, one can see the class and gender assumptions that by the turn-of-the-century came to be central to the political organization of black Richmond. While some, as the Langston Literary Association, had male members only, most of the literary societies founded in the 1880 s and 1890s had middle-class and working-class men and women members. Despite the inclusive nature of the membership and often of the officers, the form of discussion which developed privileged middle-class males. Unlike mass meetings where many people might take the floor in planned and unplanned expositions and attendees might freely interrupt or talk back to speakers, thus allowing and building mass participation, literary forums announced discussion topics in advance; charged individual members, apparently almost always male, to prepare a paper on the subject; and designated specific, also male, members to reply.

The discussions that then ensued were open to all present but the structure privileged those familiar with the conventions of formal debate. Women, who served as officers and attended in large numbers, may have joined in the discussion but their official roles were designated as the cultural arm of the forum-reading poetry, singing songs, often with political content appropriate to the occasion. The questions under consideration at the meetings often betrayed the class bias of the forum. Even when the discussions centered on some aspect of working-class life and behavior, the conversation was conducted by middle-class men. The purpose of the forums, as articulated by the Acme Literary Society, suggested the passive observer/learner position that most were expected to take: to hold "discussions, lectures, and to consider questions of vital importance to our people, so that the masses of them may be drawn out to be entertained, enlightened, and

the resultant presence of a newly migrated group within the community in the 1890 s, who sought to recreate in these communities the associational life they had left in their home communities. 
instructed thereby." ${ }^{55}$ Given the exclusionary nature of the discussion in these literary forums, even though welcoming a wide audience, it is understandable that far more working-class black men and women saw the Knights of Labor as their principal political vehicle in the late $1880 \mathrm{~s}^{56}$

In the changing circumstances of the late-nineteenth century, working-class men and women and middle-class women were increasingly disfranchised within the black community, just as middle-class black men were increasingly disfranchised in the larger society. Men and women, working-class and middle-class, at the turn-of-the-century were struggling to move back to a political authority they once had-internally and externally. As they did so they each often justified such authority along distinctively gendered and class-based lines.

African American men countered the image of themselves as uncivilized, beastly rapists - an image white southerners used to justify disfranchisement, segregation and violence - with efforts to demonstrate their own manhood and to define white males as uncivilized and savage. ${ }^{57}$ While white Richmonders told stories of black barbarity, John Mitchell, Jr., inverted the tale. The Richmond Planet, for example, repeatedly focused on the sexual perversions of white men with cases of rape and incest and spoke of white men in terms designed to suggest their barbarism: "Southern white folks have gone to roasting Negroes, we presume the next step will be to eat them. ${ }^{~} 58$ In the process of unmanning white males, however, Mitchell and others developed a narrative of endangered black women. Urban areas, once sites of opportunity for women, became sexually dangerous places for the unprotected female, easy prey to deceitful and barbarous white

55. New York Globe, 1883 and 1884, passim; Acme quote is June 23, 1883; Richmond Planet, July 26, 1890; January 12, 1895; 1890-1895, passim.

56. For a discussion of black Richmonders' participation in the Knights of Labor, see Rachleff, Black Labor in the South, chapters 7-12.

57. Efforts to demonstrate manhood increasingly took on class and status dimensions. For an example of this, see the discussion of black militias and the military ritual taken on by black fraternal orders such as the Knights of Pythias, in Barkley Brown and Kimball, "Mapping the Terrain."

58. See for example, Richmond Planet, June 11, 1891; February 24, September 22, 1900; February 16, 1901; October 25, November 1, December 20, 1902. Ida Wells-Barnett, in her struggle against the violence aimed at black women and black men, also challenged the links between white supremacy and manliness. For a discussion of Wells-Barnett's writings in this regard, see Gail Bederman, “'Civilization,' the Decline of Middle-Class Manliness, and Ida B. Well's Antilynching Campaign (1892-94)," Radical History Review 52 (Winter 1992): 5-30. Similarly, Frances Ellen Watkins Harper and Anna Julia Cooper associated Anglo-Saxon "imperialism with unrestrained patriarchal power," depicting white males as bestial devourers "of lands and peoples." Hazel V. Carby, "On the Threshold of Woman's Era': Lynching, Empire, and Sexuality in Black Feminist Theory," Critical Inquiry 12 (Autumn 1985): 265. 
males. ${ }^{59}$ Black men's political rights were essential so that they could do as men should-protect their communities, homes, families, women. The focus on manhood could, initially, be the venue for discussing domestic violence as well. For example, the Reverend Anthony Binga, sermonizing against physical abuse of one's wife drew on the discourse of manhood: "I have never seen a man whip his wife. I mean a man. Everyone who wears a hat or a coat is not a man. I mean a man." And the members of First African took as a serious issue of concern the case of a husband who had infected his wife with syphilis. ${ }^{60}$ Concurrent with the narrative of sexual danger in the city and the larger society was an implied corollary narrative of protection within one's own community. Thus the discourse on manhood could keep the concern with violence against women in the public discussion while at the same time setting the stage for issues of domestic abuse and other forms of intraracial violence, which could be evidence of the uncivility of black men, to be silenced as politically dangerous.

In drawing on the new narrative of endangered women, middle-class black women, increasingly disfranchised by the connections between manhood and citizenship in the new political discourse, turned the focus from themselves and on to the working class, enabling middle-class women to project themselves as the protectors of their less fortunate sisters. In this manner they reinserted themselves into a public political role. ${ }^{61}$ Autonomous women's organizations, such

59. The idea of sexual danger had been a part of the Reconstruction era discourse, as evidenced in the mass indignation meetings and testimonies. Then, however, it was constructed as a matter of general interest, part of the general discussion of repression of African Americans. Now a more clearly gendered discourse developed where violence against men was linked to state repression and the struggle against it to freedom and violence against women became a matter of specific interest, increasingly eliminated from the general discussions.

60. First African also excluded men found to have physically abused their wives. Binga, "Duty of Husband to Wife," in Binga, Sermons on Several Occasions, I, 304-305 (emphasis in original); FABC, II, August 6, September 3, November 5, 1883, April 7, 1884. Ultimately the members of First African were at a loss as to how to deal with the sexually transmitted disease but the persistence of the church's efforts to take it up suggests the degree to which some members considered this a serious issue.

61. It is important to note the constructed nature of this narrative. Suzanne Lebsock has taken the development of women's clubs with these concerns as possible evidence of the increased instances of exploitation of women, "Women and American Politics," 45. I suggest that the exploitation is not increased or even of greater concern, but that the venues for expressing and acting on that concern and the ideology through which this happens-both the narrative of endangerment and the narrative of protection-are the new, changed phenomenon. While the emphasis on motherhood and womanly virtues which undergirded the ideology of middle-class women as protectors may resonate with much of the work on middle-class white women's political activism in this period, it is important to bear in mind two distinctions: African American women's prior history of inclusion, not exclusion, shaped their discourse of womanhood and their construction of gender roles; they did so not in concert with 

Economy of the Hampton Negro Conference, developed to serve these functions. These associations promulgated class-specific ideas of respectability, in part justifying their public role through the need to impart such protective measures to working-class women. Specific constructions of womanhood, as manhood, thus became central to the arguments for political rights. Through discussions of manhood and womanhood, middle-class men and women constructed themselves as respectable and entitled, and sought to use such constructions to throw a mantle of protection over their working-class brothers and sisters. By increasingly claiming sexual violence as a women's issue, middle-class black women claimed a political/public space for themselves but they also contributed to an emerging tendency to divert issues of sexual violence to a lesser plane and to see them as the specific interest of women, not bound up in the general concerns and struggle for freedom. This set the stage for the masculine conception of liberation struggle which would emerge in the twentieth century. ${ }^{62}$

\section{Collective History/Collective Memory}

In July 1895 three black women - Mary Abernathy, Pokey Barnes and her mother, Mary Barnes - were convicted in Lunenberg County, Virginia, of murdering a white woman. When the women were moved to the state penitentiary in Richmond their case became a cause célèbre in the black community there. For over a year black men and women in Richmond struggled to keep the Lunenberg women from being hung or returned to Lunenberg County for a retrial, fearing that a return to Lunenberg would mean death, the women lynched at the hands of an angry white mob. The community succeeded and the three women were eventually released.

The organization of black Richmonders in defense of these women partly illustrates the increasingly gendered nature of internal community politics. Men

ideas in the larger society but in opposition as white Americans continued to deny African Americans the privileges of manhood or the protections of womanhood, reinforcing the commonality rather than the separateness of men's and women's roles.

62. James Oliver Horton and Lois E. Horton suggest that a masculine conception of liberation, based on violence as an emancipatory tool available principally to men, developed within African American political rhetoric in the North in the antebellum period. "Violence, Protest, and Identity: Black Manhood in Antebellum America," in James Oliver Horton, Free People of Color: Inside the African American Community (Washington, D.C.: Smithsonian Institution Press, 1993), chapter 4. 
and women were portrayed as having decidedly different roles in the defense; one avenue of defense was to draw on ideas of motherhood in defending these three women; and the Lunenberg women's release called forth very particular discussions of respectability and womanhood. John Mitchell, Jr., portrayed himself as the militant defender of the women. Women, led by schoolteacher Rosa Dixon Bowser, organized the Richmond Women's League for the purposes of raising funds for the women's defense, visiting them in jail and supporting their husbands and families. Through her column in the Woman's Era and her participation in the National Federation of Afro-American Women, Bowser, as did Mitchell, brought the case to national attention. The front page stories in Mitchell's Planet emphasized the Lunenberg women as mothers, especially reporting on Mary Abernathy's pregnancy and the birth of her child in her jail cell. While the pictures and stories during the fourteen-month struggle for their release portrayed the women as simply clad, barefoot, farm women the announcement of Pokey Barnes's final victory was accompanied by a photograph of her now transformed into a true Victorian woman with elegant balloon-sleeved dress, a symbol of respectable womanhood. Later descriptions of Barnes, on speaking engagements, emphasized her dress: "a neat fitting, changeable silk gown and . . . a black felt hat, trimmed with black velvet and ostrich plumes." Mitchell emphasized the importance of this transformation: "The picture showing what Pokey Barnes looked like when brought to Richmond the first time and what she appears to-day will be a startling revelation to the public and will fill with amazement the conservative people everywhere when they realize what a terrible blunder the execution of this young woman would have been." He thus suggested that it was her ability to be a respectable woman (signified superficially by a class-based standard of dress) which was the justification for his and others' protection of her. ${ }^{63}$

63. Abernathy's and the Barnes' trials, incarceration, retrials, and eventual releases can be followed in the Richmond Planet, July 1895-October 1896; Richmond Times, July 23, 1895; Richmond Dispatch, September 13-19, October 2, 23, November 8, 9, 12, 14, 16, 21, 23, 24, 27, 28, 1895; July 5, 1896. For Bowser's discussion of the formation of the Women's League to protect the Lunenberg women, see Woman's Era, October and November 1895; Charles Wesley, History of the National Association of Colored Women. The first photographs of the women in the Planet appear August 3, 1895. The first picture of "Mary Abernathy and Her Babe" was published February 15, 1896. The post-release photograph of Pokey Barnes and Mitchell's comment regarding it appeared June 27, 1896. For a description of Barnes' attire, see March 6, 1897. Discussions of the case can be found in Brundage, Lynching in the New South; and Samuel N. Pincus, The Virginia Supreme Court, Blacks and the Law 1870-1902 (New York: Garland Publishing, 1990), chapter 11. Brundage emphasizes the role of Governor O'Ferrall, and Samuel Pincus emphasizes the legal maneuverings which prevented the women's certain lynching. While emphasizing the importance of Mitchell's stands against lynching, Ann Alexander dismisses the prolonged front page coverage of the Lunenberg case in the Richmond Planet as mere sensationalism. "Black Protest in the New South: John Mitchell, 
But the year-long discussion of these women's fates (the front page of nearly every issue of the Richmond Planet from July 1895 through early fall 1896 was devoted to these cases and included pictures of the women and sketches of their cabins) occurred alongside stories about lynchings or near lynchings of black men. Importantly, therefore, when black Richmonders spoke of lynching in the late-nineteenth century, they had no reason to assume the victim as male. When a freed Pokey Barnes rode as "mascot" in the 1896 Jackson Ward election rally parade, the idea of Mitchell and other black men as defenders was reinforced. But also affirmed was the underlying understanding that violence, including state repression, was a real threat to African American women as much as men. This meant that the reconstruction of clearly delineated notions of womanhood and manhood as the basis for political activism remained relatively ambiguous in late-nineteenth century black Richmond. But issues of class and gender were increasingly evident, as when Pokey Barnes and Mitchell accepted public speaking engagements-ones in which she was clearly expected to be the silent symbol of oppression and he the vocal proponent of resistance. Barnes, countering that assumption, set forth her own understandings of her role and qualifications, contradicting the class and gender assumptions of Mitchell and of those who invited them: "she said that she was not an educated lecturer and did not have any D.D.'s or M.D.'s to her name, but she was simply Pokey Barnes, c.s. (common sense)." Her two-hour lecture on her ordeal, while giving credit to Mitchell, established herself as not only victim but also heroine. ${ }^{64}$

The rescue of the Lunenberg women by black Richmonders brought women's struggles to the fore of black rights and reaffirmed violence against women as

Jr., (1863-1929) and the Richmond Planet" (Ph.D. diss., Duke University, 1973), 152-153. Yet it is certain that it was the continuous efforts of black men and women in Richmond which created the climate of protection for Pokey Barnes, Mary Abernathy and Mary Barnes, keeping their cases in the public eye, encouraging government and judicial officials to intervene, and providing the financial resources necessary to acquire a team of prominent white men as defense attorneys and advocates for the Lunenberg women. Pamela Henry has pointed to the focus on motherhood as a central point of the Planet's defensive strategy and suggested the futility of such a strategy in an era when black women were denied the protections of Victorian womanhood. Pamela J. Henry, "Crime, Punishment and African American Women in the South, 1880-1940," paper for Research Seminar in African American Women's History, University of Michigan, Fall 1992 (cited by permission of Henry). I am uncomfortably cognizant of the fact that my narrative also, for the most part, silences Mary Abernathy and Pokey and Mary Barnes. This reflects my primary interest in understanding what this case illuminates about black Richmond. Abernathy and the Barneses, their lives and their cases, are certainly worthy of investigation in their own right; Suzanne Lebsock is currently undertaking such a study.

64. Richmond Planet, March 6, 1897. 
part of their collective history and struggle. At the same time black Richmonders struggled to create a new category of womanhood that would be respected and protected, and of middle-class womanhood and manhood that could protect. ${ }^{65}$ The plight of the Lunenberg women reaffirmed the collective history of black men and women at the same time as it invigorated increasingly distinct political vehicles for middle-class black men and women.

Just as disfranchisement, segregation, lynching and other violence denied the privileges of masculinity to African American men; segregation, lynching, sexual violence and accusations of immorality denied the protections of womanhood to African American women. Increasingly black women relied on constructing not only a respectable womanhood but, in large measure, an invisible womanhood. Hoping that a desexualized persona might provide the protection to themselves and their communities that seemed otherwise unobtainable, many black women carefully covered up all public suggestions of sexuality, even of sexual abuse. In the process issues specific to black women were increasingly eliminated from public discussion and collective memory ${ }^{66}$ In the late-twentieth century therefore

65. The narrative of class and gender, protectors and protected, was not uncontested. For example, the women of the Independent Order of Saint Luke offered a counternarrative which emphasized the possibilities of urban life not only for the middle-class but importantly the possibilities of urban life for single, working-class black women who, through their collective efforts, could be their own protectors. Still further, they suggested that women - working-class and middle-class - through their political and economic resources, could become men's protectors. Reinterpreting the standards for "race men" to require support for women's rights, they thus reinserted women's condition and rights as a barometer of freedom and progress. Some aspects of the Saint Lukes' ideas regarding the relationship between the well-being of women and the well-being of men and of the community as a whole are traced in Elsa Barkley Brown, "Womanist Consciousness: Maggie Lena Walker and the Independent Order of Saint Luke," Signs: Journal of Women in Culture and Society 14, 3 (Spring 1989): 610-633.

66. It is important to understand this desexualization of black women as not merely a middle-class phenomenon imposed on working-class women. Many working-class women resisted and forged their own notions of sexuality and respectability. But many working-class women also, independent of the middle-class and from their own experiences, embraced a desexualized image. Who better than a domestic worker faced with the sexual exploitation of her employer might hope that invisibility would provide protection? Histories which deal with respectability, sexuality, and politics in all its complexity in black women's lives have yet to be written. For beginning discussions see Darlene Clark Hine, "Rape and the Culture of Dissemblance: Preliminary Thoughts on the Inner Lives of Black Midwestern Women," Signs: Journal of Women in Culture and Society 14 (Summer 1989): 919-920; Elsa Barkley Brown, "'What Has Happened Here': The Politics of Difference in Women's History and Feminist Politics," Feminist Studies 18 (Summer 1992): 295-312; Paula Giddings, "The Last Taboo," in Race-ing Justice, En-gendering Power: Essays on Anita Hill, Clarence Thomas, and the Construction of Social Reality, ed. Toni Morrison (New York: Pantheon Books, 1992), 441463. 
many African Americans have come to link a history of repression and racial violence exclusively to challenges to black masculinity and thus to establish a notion of freedom and black liberation which bifurcates public discussion and privileges men's history and experiences. In 1991 when Supreme Court justice nominee Clarence Thomas challenged his questioners by calling the Senate Judiciary Committee hearings a "high-tech lynching," black Americans were divided in their response. Some men and women supported his analysis; others opposed either Thomas's analogy or his right to, in using such, assume the mantle of black manhood that he had so often rejected. Few people, however, questioned the assumption basic to Thomas's analogy that lynching and other forms of violence had historically been a masculine experience. Similarly, when black people across the country responded to the video of Los Angeles policemen's brutal beating of Rodney King, a narrative of state repression against black men followed.$^{67}$ The masculine focus is most evident in the widespread public discussion of "endangered" black men. While, appropriately focusing attention on the physical, economic and social violence which surrounds and engulfs many black men in the late-twentieth century United States, much of this discussion trivializes, or ignores the violence of many black women's lives - as victims of rape and other forms of sexual abuse, murder, drugs and alcohol, poverty and the devastation of AIDS. Seldom are discussions of rape and domestic violence included in summits on black-on-black crime. The masculinization of race progress which this implies often has some black leaders, looking to ways to improve the lot of men, not only omitting women from the picture but often even accepting the violence against women. What else can explain how Mike Tyson, even before he was charged with the rape of an eighteen-year-old black woman, would have been projected by ministers of the National Baptist Convention as a role model for young black men? By what standards would a man who had already publically acknowledged that he enjoyed brutalizing women have been put forward as a role model-unless rescuing black men from poverty and inner-city death at any price, including violence against women, was the standard by which the good of the race was being defined?

Such is the long term consequence of political strategies developed in the late-nineteenth century to empower black men and black women. Understandable

67. Bytches With Problems, "Wanted," is one effort by young black women to democratize the discussion of repressive violence; focusing on the often sexualized nature of police brutality against black women, they remind us that such is often less likely to be included in statistics or acknowledged in the public discussion. The Bytches (Noface Records, 1991). 
and necessary in their day, they served to maintain a democratic agenda even as black political life became more divided. Eventually, however, the experiences of men were remembered as central to African American's struggles but the experiences of women, including the physical violence-lynchings, rapes, sexual and other forms of physical abuse as employees in white homes, domestic abuseas well as the economic and social violence which has so permeated the history of black women in the United States, were not as vividly and importantly retained in our memory. We give life and validity to our constructions of race, community and politics by giving those constructions a history. Those who construct masculine notions of blackness and race progress and who claim only some forms of violence as central to African American liberation struggles are claiming/ remembering a particular history. African American collective memory in the late-twentieth century often appears partial, distorted and dismembered. The definitions and issues of political struggle which can come from that partial memory are limited. Before we can construct truly participatory discussions around a fully democratic agenda where the history and struggles of women and men are raised as issues of general interest necessary to the liberation of all, we have some powerful lot of reremembering to do. ${ }^{68}$

Elsa Barkley Brown teaches in the History Department and the Center for Afroamerican and African Studies at the University of Michigan. She is an associate editor of the two volume work, Black Women in America: An Historical Encyclopedia (Brooklyn: Carlson Publishing, 1993). Her articles have appeared in Signs, Sage, History Workshop and Feminist Studies. Her current research concerns African Americans in post-emancipation Richmond, Virginia.

68. Elsa Barkley Brown, "Imaging Lynching: African American Women, Communities of Struggle, and Collective Memory," in African American Women Speak Out: Responses to Anita HillClarence Thomas, ed. Geneva Smitherman (Detroit: Wayne State University, forthcoming). 